\title{
Taxonomic Approach to Aspergillus sp. Isolated from Caatinga Soil and Potential to Amylase Production
}

\author{
Tainã C.S. Fonseca ${ }^{1 *}$, Paulo H. da Silva ${ }^{2}$, Adriana Ferreira Souza ${ }^{3}$, Grayce Kelli Barbosa ${ }^{3}$, \\ Arminda Saconi Messias ${ }^{3}$, Carlos A. Alves da Silva ${ }^{3}$ and Galba M. Campos-Takaki ${ }^{3 *}$ \\ ${ }^{1}$ Postgraduate Program in Environmental Process Development, Catholic University of \\ Pernambuco, 50.050-900 Recife, PE, Brazil \\ ${ }^{2}$ Chemical Engineering, Catholic University of Pernambuco, 50.050-900 Recife, PE, Brazil \\ ${ }^{3}$ Nucleus of Research in Environmental Sciences and Biotechnology, Catholic University of \\ Pernambuco, 50050-590 Recife, PE, Brazil
}

*Corresponding author

\begin{tabular}{|c|c|}
\hline & A B S T R A C T \\
\hline Keywords & \multirow{4}{*}{$\begin{array}{l}\text { Filamentous fungi are very promising for the productions of many products in special } \\
\text { amylases are used in several industrial areas. The aim of this work was filamentous fungus } \\
\text { isolation from Caatinga characterized soil, and evaluation of the biotechnological potential } \\
\text { to amylase production. The Caatinga soil was characterized containing high level of } \\
\text { Calcium, followed Magnesium, Potassium, Sodium and Phosphorus, and absence of } \\
\text { Aluminium. The fungus isolated from Caatinga soil was identified as Aspergillus sp., code } \\
\text { UCP 1261. The diffusion test to amylase production showed influence of pH } 6 \text { and } \\
\text { temperature on the production of amylase production in solid by A. tamarii. The results } \\
\text { showed that the sample identified was Aspergillus tamarii UCP } 1261 \text { showed a higher halo } \\
\text { ( } 68 \mathrm{~mm} \text { ) of amylase at } 37^{\circ} \mathrm{C} \text {, pH } 6 \text { and } 72 \mathrm{~h} \text {. These results described the biotechnological } \\
\text { potential of filamentous fungi A. tamarii isolated from Caatinga biome soil isolated from } \\
\text { Caatinga biome soil as promising strain for the production of amylase. }\end{array}$} \\
\hline $\begin{array}{l}\text { Filamentous fungus, } \\
\text { Diffusion test, } \\
\text { Caatinga soil, Fungus } \\
\text { identification. }\end{array}$ & \\
\hline Article Info & \\
\hline $\begin{array}{l}\text { Accepted: } \\
\text { 23 October } 2017 \\
\text { Available Online: } \\
\text { 10 December } 2017\end{array}$ & \\
\hline
\end{tabular}

\section{Introduction}

Filamentous fungi are very promising for the production of many compounds of biotechnological and industrial interest, due to the great variety of catalytic activities, easy adaptation and possibility of enzymatic production.

There are several enzymatic productions described in the literature through biotechnological processes with the use of filamentous fungi of the genus Aspergillus (Moreira, 2013; Cunha, 2016).
The wide diversity in the characteristics of the enzymes potentiates their application in different processes in the industry, thus, faced with the demand for new amylases with prospect of applicability in the sector, there is a natural stimulus for the exploration of the microbial biodiversity, with the isolation and selection of new strains enzyme producers (Baratto, 2012).

The use of amylases in several areas of industry causes microorganisms to be 
increasingly studied and their enzymes characterized, providing a range of knowledge. Thus, the study of the amylolytic capacity of these microorganisms represents an important advance in the knowledge of the possibilities of applying their potential for the production of enzymes of industrial interest, such as amylases (Bastos et al., 2015).

\section{Materials and Methods}

\section{Microorganisms}

This study were used three samples of Aspergillus UCP 1392, Aspergillus flavus UCP 1383 and Aspergillus niger UCP 1382) isolated from Caatinga soil at Pernambuco, Brazil, and they strains were deposited in Culture Collection UCP (UniversidadeCatólica de Pernambuco), in the Nucleus of Research in Environmental Sciences and Biotechnology, Catholic University of Pernambuco, Recife, Brazil.

\section{Soil sample, chemical and granulometric analysis}

For the isolation of filamentous fungus, soil samples were collected from an area of the Caatinga located in the municipality of Serra Talhada, Pernambuco, Brazil. Different points of the site were previously demarcated and the area separated into homogeneous areas. Soil samples will be collected in zigzags, every 20 points of the field at $20 \mathrm{~cm}$ depth and taken to the Laboratory of the Nucleus of Research in Environmental Sciences and Biotechnology (NPCIAMB), Catholic University of Pernambuco.

\section{Obtaining monosporic culture}

Lineage spores were transferred from the test tube to a screw cap glass containing $2.0 \mathrm{~mL}$ of $0.1 \%$ Tween 80 solution $100 \mathrm{~mL}$ of water. The suspension was shaken to disaggregate the spores. The spores were counted in hematimeter chamber and appropriate dilutions were done in order to obtain from 20 to 100 colonies each Petri dish containing BDA culture medium $(4.0 \mathrm{~g}$ potato, $20.0 \mathrm{~g}$ dextrose, $15.0 \mathrm{~g} \mathrm{Agar}, 1000 \mathrm{~mL}$ of distilled water, $\mathrm{pH} 5.6+0.2$ at $25^{\circ} \mathrm{C}$ ). Plates were maintained at room temperature. Spore germination was observed from 12 to 72 hours of growth. After germination of the spores with the aid of the magnifying glass, a single spore was transferred to a test tube, containing BDA, for the development of the colony.

\section{Fungus identification}

The strain was identified according to the Aspergillus identification manual described by Klich (2002) and Samsom et al., (2005). The isolate was inoculated in the following culture media: Czapek yeast autolysate (CYA) agar, (Czapek concentrate $10 \mathrm{~mL}$, sucrose $30 \mathrm{~g}$, yeast extract $5 \mathrm{~g}, \mathrm{~K}_{2} \mathrm{HPO}_{4} 1 \mathrm{~g}$, agar $20 \mathrm{~g}$ and distilled water $1000 \mathrm{~mL}$ ) and Malt Extract Agar (MEA) (malt extract 20g, peptone $1 \mathrm{~g}$, glucose $20 \mathrm{~g}$, agar $20 \mathrm{~g}$ and distilled water $1000 \mathrm{~mL}$ ). The media were adjusted to $\mathrm{pH} 6$ and autoclaved at $121^{\circ} \mathrm{C}$ for 15 minutes. Inoculations were made from spore suspension in a semi-solid agar solution containing $0.2 \%$ and $0.05 \%$ Tween 80 , using a micropipette for inoculation at three equidistant points and incubated for seven days at 25 and $37^{\circ} \mathrm{C}$. After 7 days, the diameters of the colonies were measured and the macroscopic characteristics were observed: colony texture, sporulation degree, conidia color, texture and color of the mycelium, presence of pigment colors and exudate.

For the microscopic observations, the mycelium was removed from the areas where the adjacent colonies were closer, from the area of the colony where the conidia were 
beginning to develop. The slides were assembled with lactic acid (85\%) and drops of $70 \%$ ethanol to disperse the conidia and to prevent air bubbles when mounted on lactic acid. Microscopic structures, such as length, width and texture of conidiophores, conidial head shape, vesicle diameter, length of metulae (if present) and phialides, diameter, shape and texture of ascospores and conidia (if present), form and color of cleistothecia/ sclerotia (if present).

\section{Evaluation of amylase production}

To determine the amylase-producing Aspergillusspp sample, tests were performed to determine the amylase activity in solid medium according to the Hankin and Anagnostakis (1979) methodology, adding $2 \%$ soluble starch to the medium. The culture medium was dispensed into Petri dishes, and after solidification holes were drilled in the center of the plates and inoculated with 100 $\mu \mathrm{L}$ of the fungal spore suspension. The plates were incubated at different temperatures $(28$, 37 and $\left.45^{\circ} \mathrm{C}\right)$ and $\mathrm{pH}(6 ; 7 ; 8)$ for $96 \mathrm{~h}$. After the enzymatic detection period, they were developed with a $0.1 \mathrm{~N}$ solution of iodine for 5 minutes. The formation of a transparent halo around the grown colonies evidenced the presence of amylase. All assays were performed in triplicate.

\section{Results and Discussion}

\section{Caatinga soil chemical analysis}

The analysis of the physical characteristics of the Caatinga soil was during the summer season that showed in its composition the presence of sand between 33 and $23 \mathrm{~g} \mathrm{Kg}^{-1}$ and of clay between 21 and $23 \mathrm{~g} \mathrm{Kg}^{-1}$ according to granulometry test. For the gravimetric test, $9.68 \%$ moisture was detected, $\mathrm{pH}$ around 5.9. The study of the chemical composition of the soil was detected of high level of calcium, followed magnesium, sodium, potassium, and phosphorus, and absence of aluminum according to Table 1.

\section{Filamentous fungus identification}

According to classical identification, based on the macroscopic and microscopic characteristics, the isolate belongs to the species Aspergillus tamari Kita. The colonies grown in MEA showed white mycelium, colorless reverse, conidiophore of irregular lengths that guarantee a coarse texture and conidia were yellowish-brown with aging of the colony. In CYE, they had a diameter of 70 $\mathrm{mm}$ at 25 and $37^{\circ} \mathrm{C}$ showing white mycelium, colorless to yellowish gray; Colony floccose to flat, conidia of olivaceous brown color with the aging of the colony.

Microscopic observations showed radial to columnar conidial heads, conidiophores with a rough and colorless surface, globular pyriform vesicles between 20 and $45 \mu \mathrm{m}$ wide, predominantly biseriate (presence of metulae and phalides), as shown in Figure 1A, rarely was found uniseriate (only phialides), metulae/phialides in most cases covering the whole surface of the vesicle, metulae reaching 4 to $8 \mu \mathrm{m}$ and phialides between 4 and $6 \mathrm{~mm}$ in length.

Globose conidia, roughly rough with thick walls, as shown in Figure 1B presenting roughly $5 \mu \mathrm{m}$ to $8 \mu \mathrm{m}$ in diameter, rarely $13 \mu \mathrm{m}$ in diameter.

The data reported correspond to the studied literature Klich (2002), which mentions being a species originally isolated from the tamari sauce and also considered a common fungus of the soil, especially in tropical soils. The Caatinga region is one of the most threatened biome in Brazil, where much of its area has been desertified, mainly due to extreme weather conditions. 
Table.1 Chemical characteristics of the Caatinga soil of the state of Pernambuco, Brazil

\begin{tabular}{c|c}
\hline Chemical elements & Content \\
\hline Calcium & $8.6 \mathrm{cmolc} / \mathrm{dm} 3$ \\
Magnesium & $3.55 \mathrm{cmolc} / \mathrm{dm} 3$ \\
Sodium & $0.01 \mathrm{cmolc} / \mathrm{dm} 3$ \\
Potassium & $0.15 \mathrm{cmolc} / \mathrm{dm} 3$ \\
Aluminum & Negative \\
Phosphorus & $2.0 \mathrm{mg} / \mathrm{dm} 3$ \\
\hline
\end{tabular}

Table.2 Influence of temperature and $\mathrm{pH}$ for detection of amylase production by Aspergillus strains for 72 hours of culture

\begin{tabular}{ccccc}
\hline & & \multicolumn{3}{c}{ Temperature $\left({ }^{\circ} \mathrm{C}\right) /$ Amylase Halo $(\mathrm{mm})$} \\
\cline { 2 - 5 } Fungi & $\mathrm{pH}$ & 28 & 37 & 45 \\
\hline Aspergillus tamari & 6 & 43 & 68 & 53 \\
UCP 1261 & 7 & 40 & 65 & 35 \\
Aspergillus UCP & 8 & 44 & 37 & 51 \\
1392 & 6 & 42 & 42 & 51 \\
& 7 & 46 & 43 & 51 \\
Aspergillus flavus & 8 & - & - & 40 \\
UCP 1383 & 6 & - & - & - \\
& 7 & - & - & - \\
Aspergillus niger & 8 & - & - & - \\
UCP 1382 & 6 & 35 & 30 & - \\
\hline
\end{tabular}

(-) No formation of the characteristic halo

Fig.1 Aspergillus tamarii. (A) Conidia head (400x); (B) conidia (1000x)

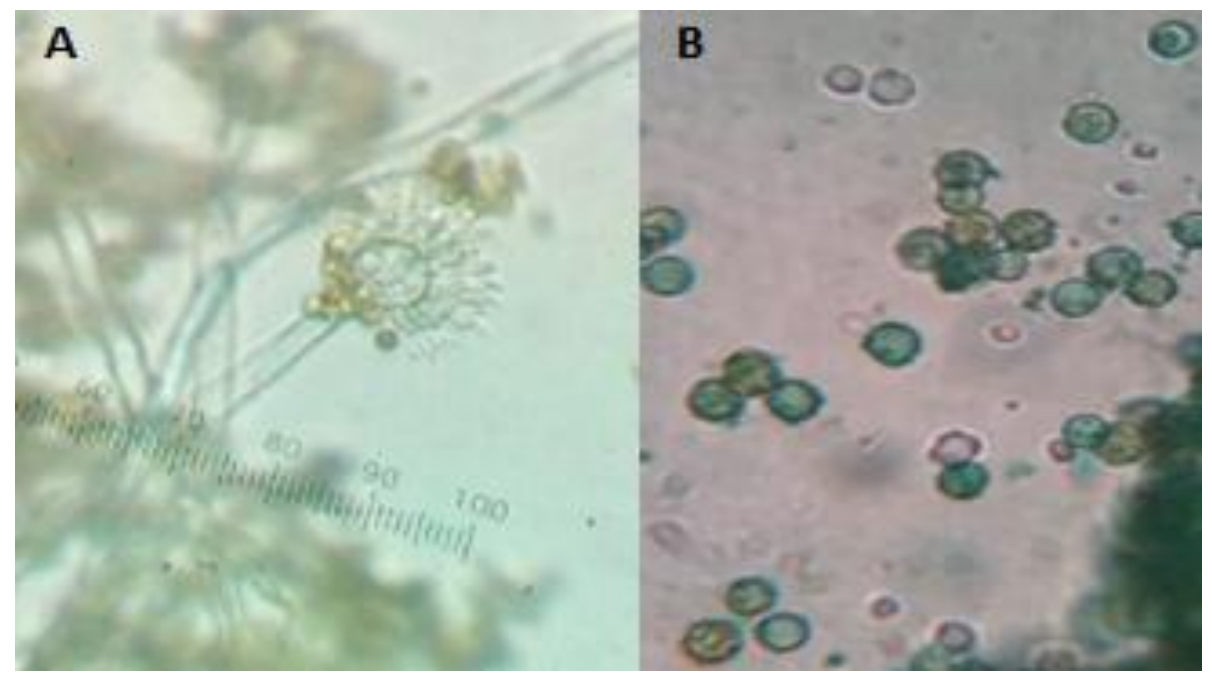


Despite adverse weather conditions there, such as solar radiation, low rainfall, etc., many fungal species are isolated from the soil of the semi-arid region. Cavalcanti and Maia (1994) isolated cellulolytic fungi in the Caatinga semi-arid soil. Costa et al., (2006), studied Hiphomycetes of soil contaminated by ores in the semi-arid region of the Northeast, Santiago and Souza-Motta (2006) that isolated Mucorales from the Caatinga soil. Several species of the genus Aspergillus and among other genera were isolated from the Xingó region in the Northeast by Queiroz et al., (2006), among them 28 A. tamarii strains were found in the three Alagoan municipalities studied. Aspergillus species showed influence of temperature and $\mathrm{pH}$ on amylase production. According to the data, Aspergillus tamarii (UCP 1261) showed higher potential to produce amylase extracellularly after 72 hours of incubation at $\mathrm{pH} 6$ at $37^{\circ} \mathrm{C}$, resulting in the formation of characteristic halo with a diameter of $68 \mathrm{~mm}$ (Table 2). Results considered inferior were obtained by Souza et al., (2008), after testing the potential of Basidiomycetes samples in the amylase production, which resulted in the characteristic halo formation with dimensions between 6.20 and $22.30 \mathrm{~mm}$ after growth at $28^{\circ} \mathrm{C}$. Moreover, Alves et al., (2002) carried out the study of amylase production with Mucor spp. and observed results similar to those obtained in this study, demonstrating the formation of the characteristic halo with dimensions between 46-85 $\mathrm{mm}$ after $72 \mathrm{~h}$.

\section{Conflict of Interest}

The authors confirm that this article content has no conflict of interest.

\section{Acknowledgments}

The authors wish to thank the Brazilian Research Council (CNPq), Brazil, the Coordination for Improvement of Higher
Level Education (CAPES), Brazil and the Foundation for Support of Science and Technology of the State of Pernambuco FACEPE, Brazil. Special thanks are given to Catholic University of Pernambuco for making facilities and infrastructure available for the conduct of this research.

\section{References}

Alves M.H., Campos-Takaki G.M., Porto A.L.F. and MilanezA.I. Screening of Mucor spp. for the production of amylase, lipase, polygalacturonase and protease. (2002) Brazilian J. Microbiol., 33: 325-330.

Baratto, C. M., Salamoni, S. P., Costa, R., Oliveira, C. B. and Locatelli, G. O. (2012) Seleção de microrganismos produtores de enzimas hidrolíticas isolados da região do meio oeste de Santa Catarina, Brasil. EvidênciaCiência e Biotecnologia. 11(2):15-28.

Bastos, C. M. S., Carreiro, S. C., Costa, S. T. C., de Abreu-lima, T. L. andZuniga, A. D. G. (2015) Efeito das condições de cultivo na produção de amilase por duas linhagens de leveduras. Revista Brasileira de Biociências. 13(3).

Cavalcanti M.A. and Maia L.C. (1994) Cellulolytic fungi isolated from an alluvial soil in a semi-arid area of the northeast of Brazil. Rev. Microbiol.25: 251-4.

Costa I.P., Cavalcanti M.A.Q., Fernandes M.J.S. and Lima D.M. (2006) Hyphomycetes from soil of an area affected by copper mining activities in the State of Bahia, Brazil. Brazilian Journal of Microbiology. 37: 290-295.

Cunha, J. R. B., Santos, F. C. P. D., Assis, F. G. D. V. D. and Leal, P. L. (2016) Cultivation of Penicillium spp. in soy bean crop residues for production of cellulase, protease and amylase. Revista Ceres. 63(5): 597-604. 
Hankin L. and Anagnostaki S.L. (1979) The Use of Solid Media for detection of Enzymes Production by Fungi. Mycologia. 67:597 - 607.

Klich, M.A. (2002) Identification of Common Aspergillus species. Amsterdam: Centraal bureauvoor Schimmelautures, 116.

Moreira, A.G. Lima, A.F., Pedrinho, S.R.F, Lenartovicz, V., Souza, C.G.M. and Peralta, R.M. (1999). Produção de amilases por Aspergillus tamarii. Production of amylases by Aspergillus tamarii. Revista de Microbiologia. 3: 157-162.

Queiroz, C.M. A. Oliveira, L.G., Fernandes, M.J. and Lima, D.M. (2006) Fungos filamentosos isolados do solo em municípios na região Xingó, Brasil. Acta bot. Bras.20:831-837.

Samson, R.A., Hoekstra, E.S., Frisvad, J.C. (2004) Introduction to food-and airborne fungi, Centraal bureauvoor Schimmel cultures (CBS). 7.

Santiago A, Souza-motta CM. Mucorales isolados do solo de mineração de cobre e produção de amilase e inulinase. (2006) Acta Botanica Brasilica, 20, 641-647.

Souza, H.Q., Oliveira, L.A. and Andrade,J.S. (2008) Seleção de Basidiomycetes da Amazônia para produção de enzimas de interesse biotecnológico. Ciênc. Tecnol. Alim. 28: 116-124.

\section{How to cite this article:}

Tainã, C.S. Fonseca, Paulo H. da Silva, Adriana Ferreira Souza, Grayce Kelli Barbosa, Arminda Saconi Messias, Carlos A. Alves da Silva and Galba M. Campos-Takaki. 2017. Taxonomic Approach to Aspergillus sp. Isolated from Caatinga Soil and Potential to Amylase Production. Int.J.Curr.Microbiol.App.Sci. 6(12): 3023-3028. doi: https://doi.org/10.20546/ijcmas.2017.612.353 